Nunt. Antiquus, Belo Horizonte, v. 15, n. 1, p. 155-184, 2019

\title{
The Tenth Muse: Cinema
}

\section{A décima Musa: Cinema}

\author{
Martin M. Winkler \\ George Mason University, Fairfax, Virginia / United States \\ mwinkler@gmu.edu
}

\begin{abstract}
In Classical Antiquity, the nine Muses were the patron goddesses of all arts and sciences and the inspiration for creative minds, especially poets. With the march of technology until today, their realm has significantly expanded. Jean Cocteau, among others, added a tenth Muse to the original nine: that of the cinema. This article surveys various films in which one or more of the Muses play major parts; it also pays homage to the actresses who portray them and to others who may be regarded as their screen relatives.
\end{abstract}

Keywords: classical mythology; films about antiquity; Hesiod; Homer; Muses in film; Polyhymnia; Terpsichore.

Resumo: Na Antiguidade Clássica, as nove Musas eram as deusas patronas de todas as artes e ciências e a inspiração para as mentes criativas, especialmente a dos poetas. Com o desenvolvimento da tecnologia até hoje, seu reino se expandiu significativamente. Jean Cocteau, entre outros, adicionou uma décima Musa às nove originais: o cinema. Este artigo inspeciona vários filmes nos quais uma ou mais das Musas têm um papel representativo; e também homenageia as atrizes que as interpretam e as que podem ser vistas como suas parentes na tela.

Palavras-chave: mitologia clássica; filmes sobre a antiguidade; Hesíodo; Homero; Musas no cinema; Polímnia; Terpsícore.

Mênin aeide, thea and Andra moi ennepe, Mousa, polytropon: these words open our oldest works of literature, Homer's Iliad and Odyssey. The epic poet calls upon a Muse for inspiration to sing about the wrath of Achilles during the Trojan War and about the return of Odysseus from that war. Homer did not identify his Muse or Muses, indicating that all of them are present at the origin of human arts and culture. In 
Homer's epic poems, powerful gods- - Hades, Zeus, Helios-are named a few lines later, but the beginnings of Western literature start with the nine sisters. Ladies first! One of the Homeric Hymns, addressed to the Muses and Apollo, their leader (Mousagetês), explains why:

With you, Muses, I begin, and with you, Apollo, and you, Zeus; since from you, Muses, and far-shooting Apollo the singers of tales here on earth and the musicians descend, as from Zeus do the kings. Hallowed is he whom the Muses love, for sweetly sung speech flows from his mouth. Greetings, you children of Zeus, and honor my song, too. I, in turn, will be mindful of you and of other song. ${ }^{1}$

Accordingly, Apollo was frequently depicted together with the Muses. The marble statues of him and the Muses now in the Vatican's Museo Pio Clementino (in the Hall of the Muses, of course) and the charming frescoes by Baldassare Peruzzi in the Pitti Palace in Florence (FIGURE 1) and by Rafael in the Vatican (FIGURE 2) are just a few of countless such representations. ${ }^{2}$ Although some ancient sources mention two, three, four, five, seven, or eight Muses, the canonical number nine for the daughters of Zeus and Mnemosyne, the goddess Memory, came to overshadow all others. ${ }^{3}$ The Greek Muses were also associated and eventually identified with the Italic Camenae (Livius Andronicus, Odusia 1.1). Our earliest detailed account of inspiration by the Muses occurs in Hesiod, who states that he received his poetic gifts from them when he was a young man tending his flocks on Mt. Helicon (HESIOD, Theogony, 22-34). This mountain, together with Olympus and Parnassus, has been closely associated with Muses and poetry at least since then.

\footnotetext{
${ }^{1}$ Homeric Hymns 25 ("To the Muses and Apollo"), my translation. These hymns were attributed to Homer in Antiquity (hence their collective name) but are of a later date. Lines 2-5 of this one are taken from Hesiod (Theogony 94-97). My term musicians (a word derived from Muse) is, in the original, "kithara players" and indicates lyric rather than epic poetry.

${ }^{2}$ Except for screenshots, which are identified, all illustrations are either in the public domain, taken from the author's collection, or used by permission. Images appear in accordance with fair-use regulations.
}

${ }^{3}$ So already in Hesiod (Theogony 75-79). 
FIGURE 1 - Baldassare Peruzzi (Pitti Palace, Florence)

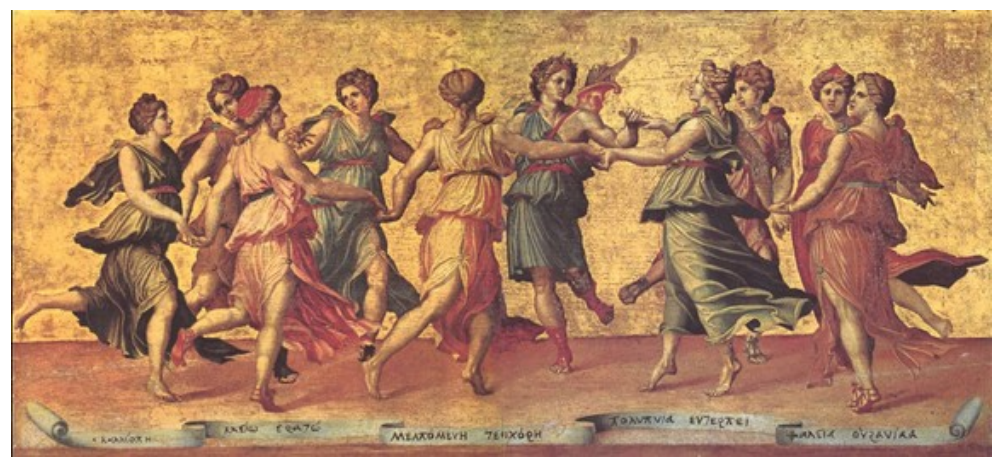

FIGURE 2 - Rafael (Vatican)

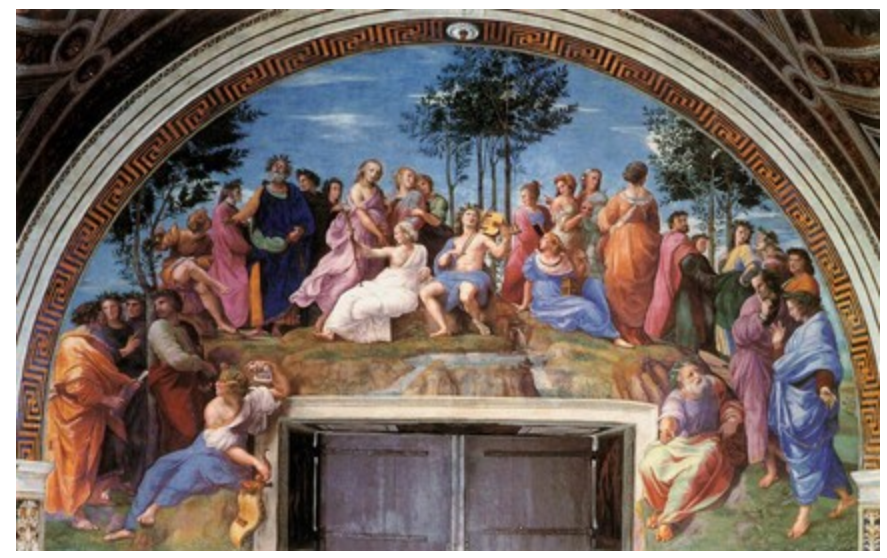

\section{Jean Cocteau and the Tenth Muse}

In the march of time from Archaic Antiquity to our age there also occurred a significant march of technology, one that has made a number of new media available to creative artists. The chief among technological marvels today is our ability to tell stories in moving images. So the cinema and later developments like television and digital media necessitate, as it were, an increase in the number of the Muses. Jean Cocteau, as poet, playwright, painter, draughtsman, screenwriter, film director, and occasional actor a master of both verbal and visual arts, addressed himself to this need when he personified the cinema as "the tenth Muse." He was right to do 
so. Here are some of his words in homage to this new Olympian: "FILM, the new Muse" (1920) (COCTEAU, 1992, p. 23); "the Muse of Cinema, whom the nine sisters have accepted into their close and strict circle" (1953) (COCTEAU, 1992, p. 123); "the Muse of Cinema is the youngest of all muses" (1959) (COCTEAU, 1992, p. 56). ${ }^{4}$ Lotte Reiniger, the cinema's great artist of silhouette films (Scherenschnitt), once created an image of the traditional nine Muses joined by her new sister, whom Reiniger charmingly christened Cinoterpe (FIGURE 3). Who could resist her?

FIGURE 3 - Lotte Reiniger, Cinoterpe

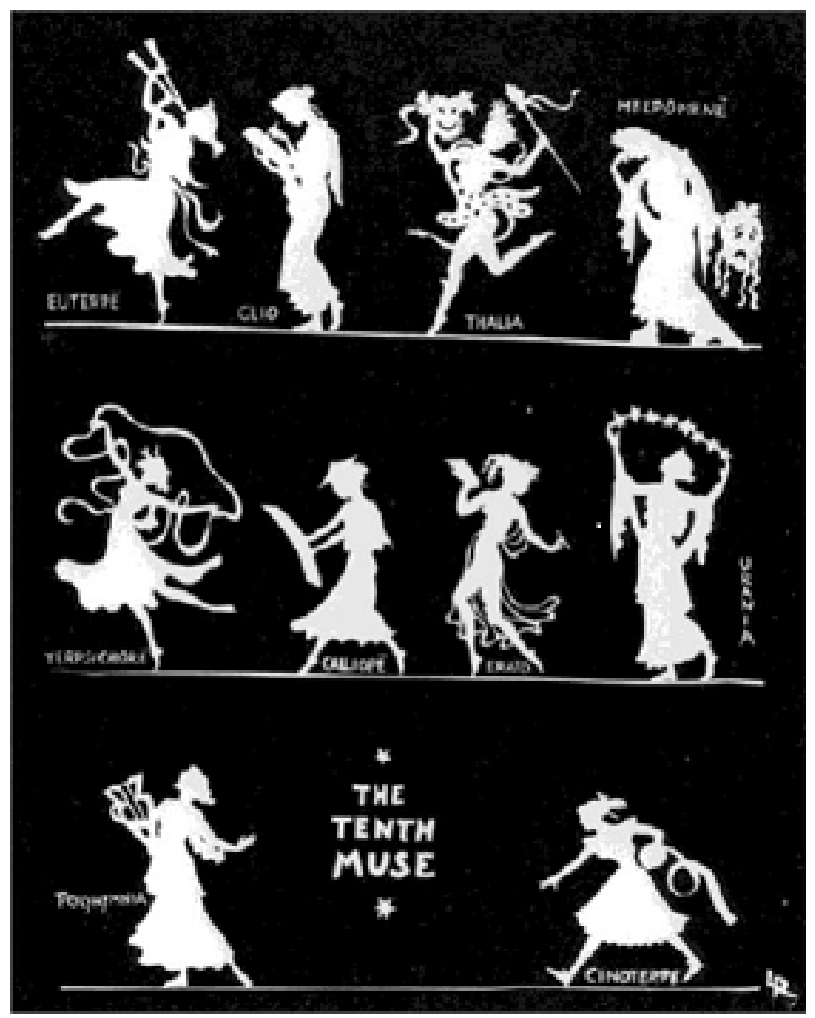

${ }^{4}$ Cocteau (1992, p. 176-177) provides a characterization of "the young Muse of Cinema" and "her sacred mission." See further Fraigneau (1972, p. 12-13). Cocteau was not the only one, and may not have been the first, to call the cinema the tenth Muse; see further examples in Marcus (2007, p. xiii-xv). Scholars continue the tradition, e.g. Pucci (2005) and Gagetti (2007). 
The following pages introduce a few specific incarnations of the Muses on screen, under the aegis of Terpsichore as played by Rita Hayworth in Down to Earth (1947) (FIGURE 4). ${ }^{5}$ Hayworth was regularly apostrophized in divine terms: "Rita Hayworth... is... one of many embodiments of our most prevalent national myth — the goddess of love" (LIFE'S Cover, 1947). ${ }^{6}$ So I invoke her in pseudo-Homeric but sadly unmetrical words: Mousas moi ennepe, Rita, polytropas kinêmatographikas!

FIGURE 4 - Rita Hayworth (painting by Ned Scott)

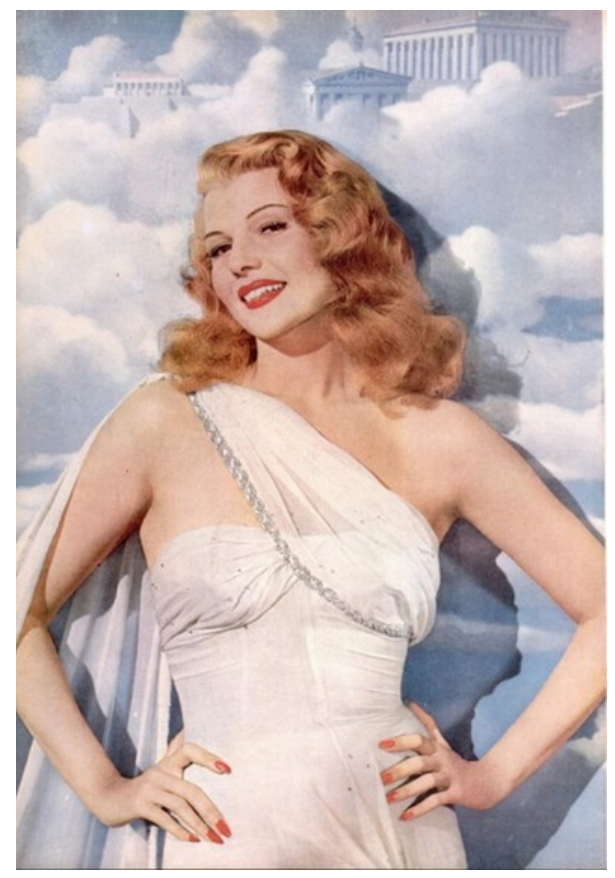

\footnotetext{
${ }^{5}$ This image preceded and introduced Sargeant (1947), one of the most amusing and revealing contemporary articles on this film.-Here and below, I incorporate some material from Winkler (2009, p. 70-121) (chapter titled "Divine Epiphanies: Apollo and the Muses").

${ }^{6}$ The same page credits the painting here reproduced to "Ned Scott for Columbia Pictures," the studio that released the film. A photo of Hayworth (not as a Muse) appears on this issue's cover.
} 


\section{New Life for the Muses}

Just how the cinema may make it possible for classical Muses to come to our screens is demonstrated in the feature-length Disney cartoon Hercules (1997). It begins with views of a museum's dusky storage room, in which various classical works of art seem to have been leading a sleepy and forgotten existence. In the center of the room the camera finds a large amphora - not too accurate in its proportions - that shows Hercules and the Nemean Lion. On its neck we discern a painting of five female figures, with a Meander decoration underneath. These women, it will soon turn out, are the Muses. Presumably, animating nine would have posed too complex a challenge to the film's creators. Coming from multicultural America, they are dark-skinned and will move to a gospel beat. These Muses seem to have been awakened by the orotundity of the voice of off-screen narrator Charlton Heston, who had previously played famous figures from Biblical and Classical Antiquity: Moses, Ben-Hur, John the Baptist. They hear his portentous introduction to the story about Hercules and react with indignation: "We'll take it from here, darling!" Accompanied by Motown music, the ladies introduce themselves to viewers: "We are the Muses, goddesses of the arts and proclaimers of heroes." Soon after, one of them jumps out of her picture frame; another bends down, lifts up part of the Meander band as if it were a carpet, and arranges it as a flight of stairs. The Motown Muses descend (FIGURES 5-6). They will reappear at appropriate intervals in the film to comment on its action, forming a clever kind of Greek chorus. The Meander also reminds us of a filmstrip. The association of Muses and cinema could not have been expressed more charmingly. Hercules is not a lesson in mythology - no film ever is — but it is a witty and irresistible Americanization. Beckmessers, be gone! As one of the five had told the narrator earlier: "Lighten up, dude!" Viewers of this and all other mythbased films would be well advised to heed her words. Reader, remember them, too, as you proceed! Two Muses, as we will see next, were granted particularly remarkable screen incarnations. 
FIGURES 5-6 - Hercules (1997), screenshots
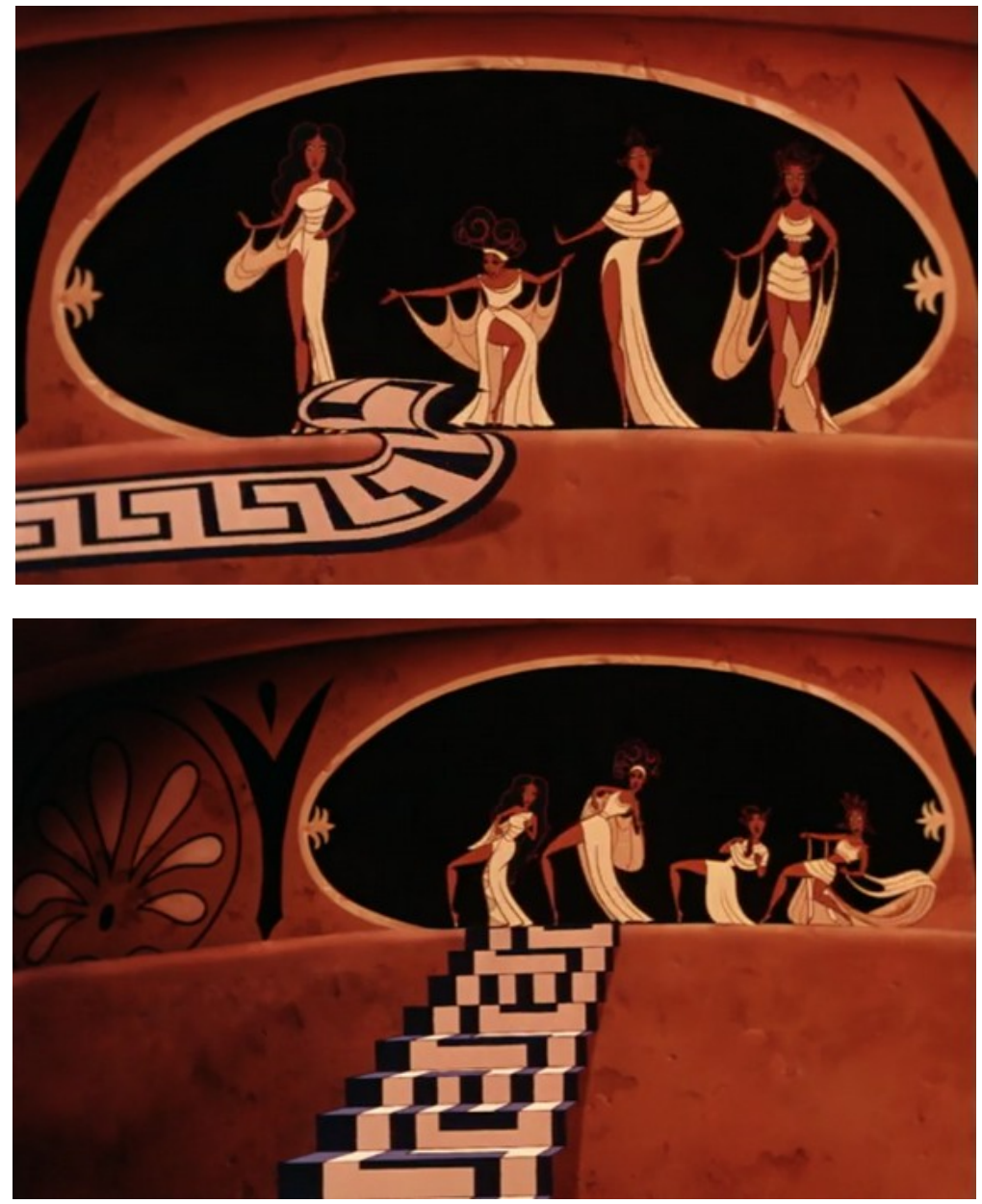

\section{Terpsichore Comes to Broadway}

As mentioned, Rita Hayworth played Terpsichore in Down to Earth (FIGURE 7). One poster showed her in full flight (FIGURE 8). A poster for the Italian release, titled Bellezze in cielo ("Heavenly Beauties"), is especially charming. It combines the classical with the modern (FIGURE 9). A Broadway producer is in rehearsal for a musical 
to be called Swinging the Muses. The American singer-dancers who play the Muses on stage introduce them to those in the audience who may need a little help with classical mythology: "we're the goddesses who / bring art and culture to you." Then the American Terpsichore takes over:

The jive is that from way back when

our kiss could inspire many men

to sing, to dance, to act, to paint;

it's up to us if they is or ain't.

For instance, take a chick like me;

they call me Terpsichore.

I'm the goddess of song and dance;

I put the ants in the dancers' pants.

FIGURES 7-8 - Down to Earth (1947), posters
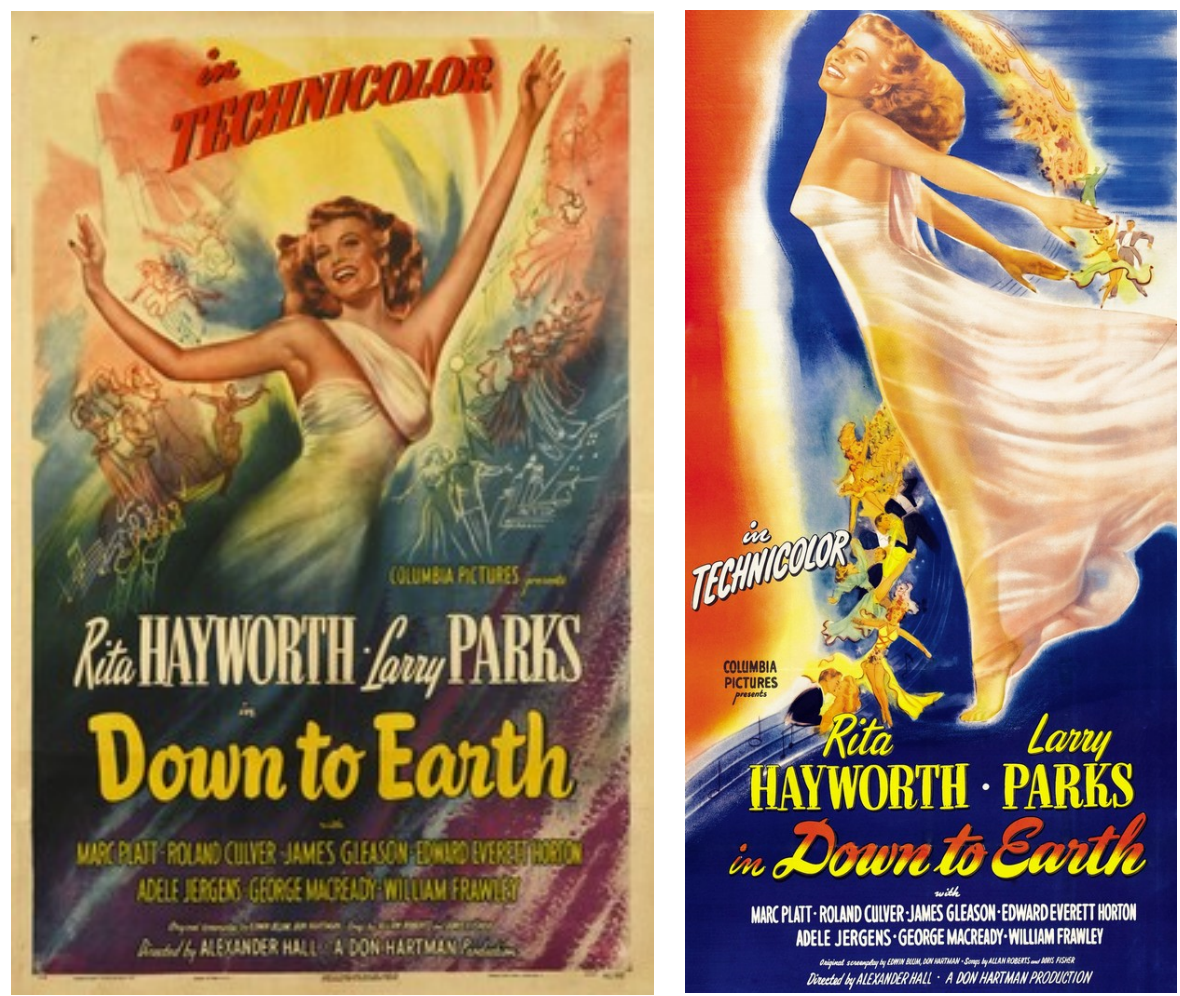
FIGURE 9 - Down to Earth (1947), Italian poster

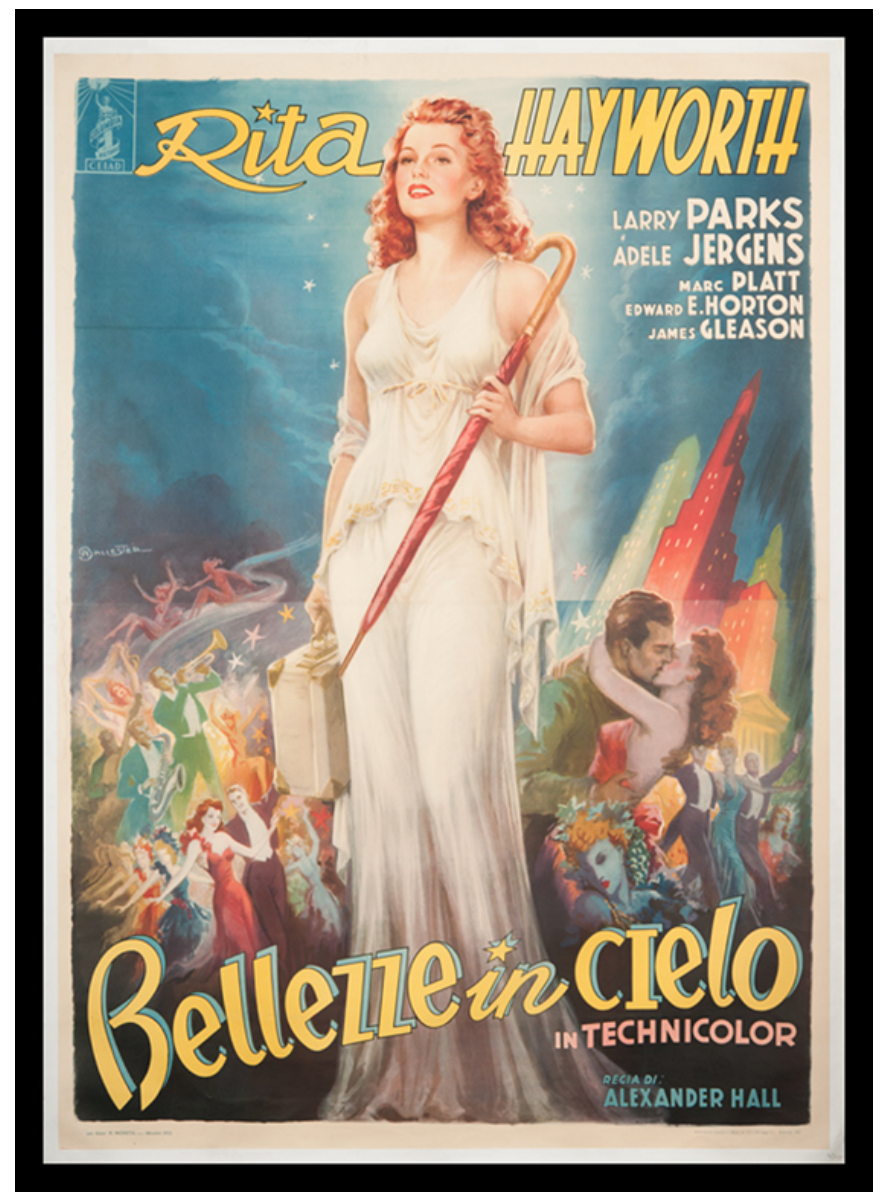

Is that a way to characterize the divine ladies? It is, if you are a 1940s hipster; it ain't if you are the real Terpsichore. The latter finds out about the show and is outraged (FIGURE 10). She is fluent in English, of course; screen Muses never have a problem with modern languages. Disguised as a modern mortal, she comes down to earth to teach the brash producer some of the basics about things classical. These include nectar and ambrosia, but unfortunately her screenwriters are a bit unclear on these particular concepts. Since this is Hollywood, a romance between 
the producer and the Muse ensues, and they even get to live happily ever after. Their intentionally nonreligious Hereafter echoes director Alexander Hall's earlier comedy Here Comes Mr. Jordan (1941), which dealt with reincarnation. Before the happy ending, Rita gets to dance in a pseudo-classical "Greek Ballet," the film's biggest production number. Its music was specially composed by Mario Castelnuovo-Tedesco and staged in classical architecture under somber lighting to convey to audiences a sense of awe and high seriousness before the glory that was Greece (FIGURE 11). Cultcha galore! We even see love goddess Rita surrounded by bronze Cupids. The ballet counterbalances one of the most bizarre numbers in "Swinging the Muses" and in the history of screen musicals. The down-to-earth Muse - she is such in both senses of the term - proposes to marry not one but two men! The lyrics include statements such as "This can't be legal; it sounds too good!" and "Get out the ipso, look up the facto!" One of the prospective bridegrooms observes to the other: "This must be the new thing that everybody's talking about." The Americanized Muse provides a reason for her bigamous proclivities: "I'll get two kisses from two pairs of lips, / two little mink coats in case one rips." She must have been infected with modern materialism: a touch of two minks! Too bad that the sassy number is musically and choreographically rather undernourished. But the stage set for their Home Sweet Home displays an appropriate maxim: ZEUS BLESS OUR HOME. Toward the end of this song two more men drop in. But any danger of immorality is banished forthwith, and the middle-class citizens in the audiences of either "Swinging the Muses" or Down to Earth need not be shocked by such potential double bigamy. Terpsichore makes it clear that there will be no bedroom hanky-panky for any of the men. Their marital duties will be restricted to household chores. 
FIGURES 10-11 - Down to Earth (1947), screenshots
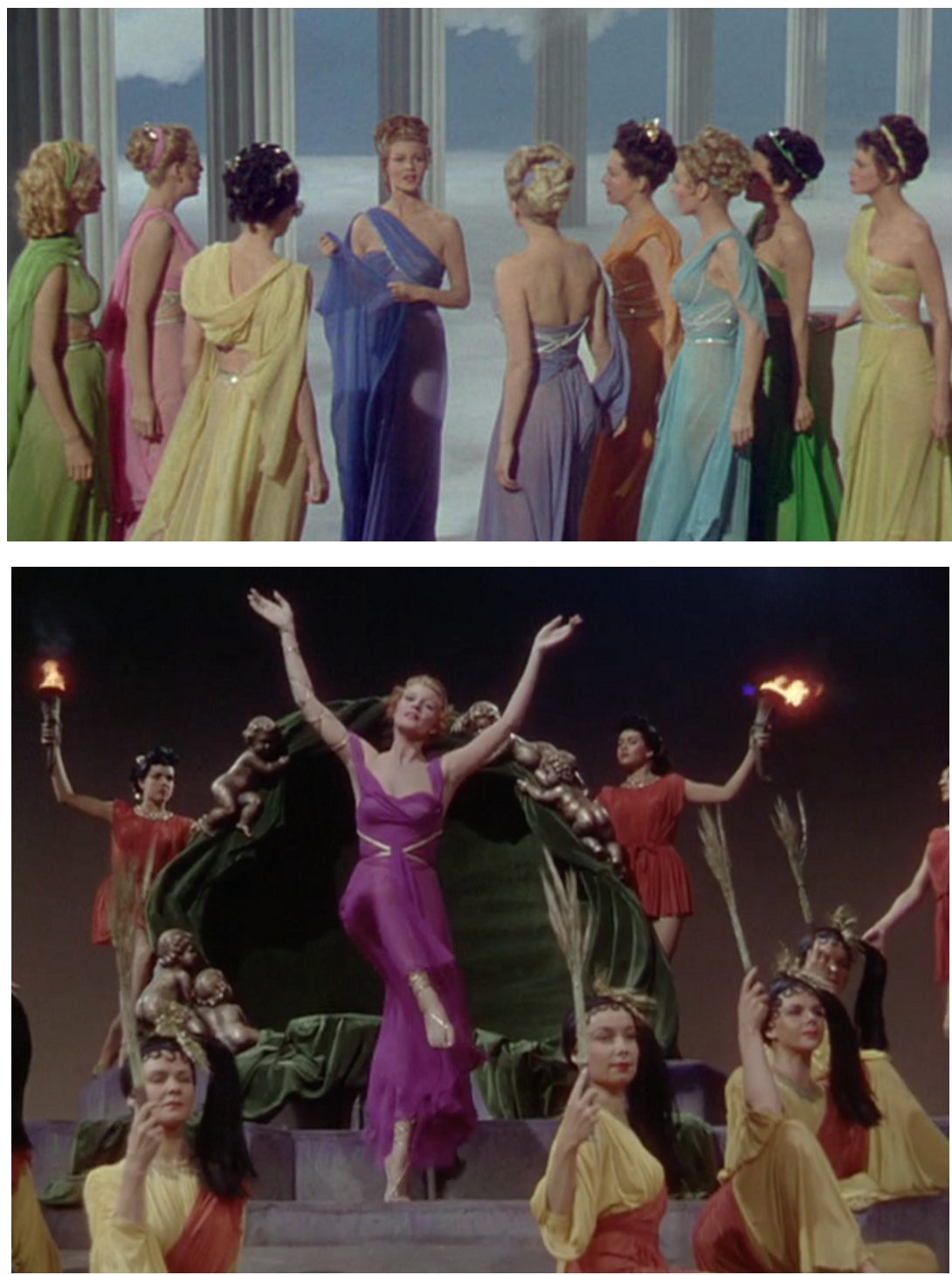

\section{Polyhymnia Finds Love in Copenhagen}

In 1951, Polyhymnia descended to Denmark's capital in Torben Anton Svendsen's Mød mig på Cassiopeia ("Meet Me on Cassiopeia", 
FIGURE 12). Cassiopeia is Polyhymnia's favorite retreat. A young composer is struggling to write a score for a stage musical. Not the least reason for his composer's block is the fact that his ex-wife, whom he still loves, is the star of the show and that he will have to appear with her on stage. Fortunately, he has an aunt knowledgeable about mythology. She advises him to call on Polyhymnia for inspiration because this particular Muse "takes care of composers." She then magically materializes in his apartment (FIGURE 13). Since she is played by beauteous Bodil Kjer, he is quite smitten with her (FIGURE 14). Unlike Hollywood's swinging Muses, Polyhymnia has never been in love, as her virginal white dress indicates. She has never even been kissed, but she is ready: "Venus says that kissing is wonderful."

FIGURE 12 - Meet Me on Cassiopeia (1951), poster on DVD cover

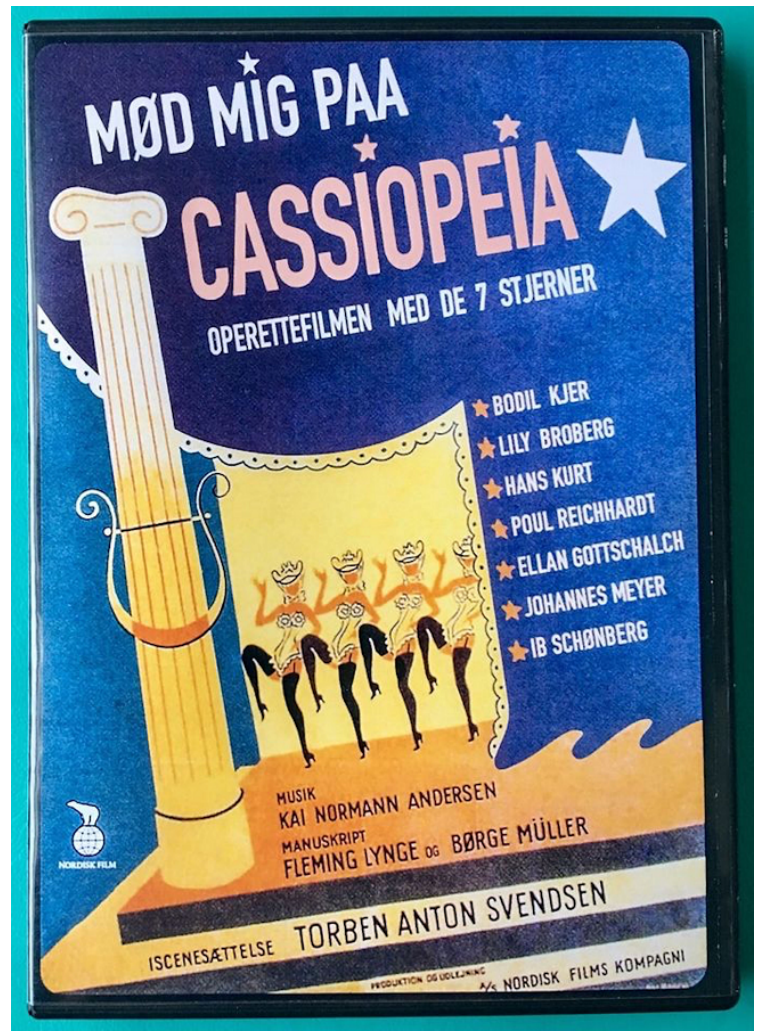


The film's plot is smarter than viewers might at first expect. The budding romance between composer and Muse does not work out because of the former's wife. But since this, too, is a romantic musical-comedy, Polyhymnia clearly deserves a sweetheart. He appears in the shape of a dashing aviator, who genuinely falls for her, as she does for him. Zeus, who is a bit of a meddlesome parent, has become concerned about his daughter's earthly adventures and comes down to earth as well. But he gets tipsy, loses his lightning bolt, the source of his supernatural powers, and develops a thing for the aunt. He forces Polyhymnia to leave the earth but cannot stop her love for the aviator. So the daring young man in his flying machine ascends up, up, and away to meet her on Cassiopeia. Zeus' thunder forces him to return. Is their romance doomed? Not at all, for in a charming final twist the aviator meets a pretty stewardess who looks exactly like his Polyhymnia.

The film has two musical highlights. One is the jaunty "Raise Your Hat and Swing Your Cane," which the composer performs in the presence of a bevy of bathing beauties. The other is "Between Heaven and Earth," Polyhymnia's solo number about her solitude at a moment when she feels abandoned. She is alone on a dark and deserted theater stage. "A Muse on her own has a hard time in this world. / She's not in her place between heaven and earth," she begins, then waxes philosophical: "The life of a Muse, what is it worth? / It's just a speck of dust between heaven and earth." Accordingly, her conclusion is pure melancholy: "No, Muses should stay at home far away in their world; / their hearts are broken between heaven and earth." This Muse got the blues. Which male in the audience would not want to rush up to the screen and into the film to comfort her? Fortunately, such will not be necessary. The composer had already told her: "Nothing is impossible in love." This is an impeccably classical maxim. In Virgil's famous words: "Love conquers all."”

\footnotetext{
${ }^{7}$ Virgil, Eclogues 10.69: omnia vincit amor.
} 
FIGURES 13-14 - Meet Me on Cassiopeia (1951), screenshots
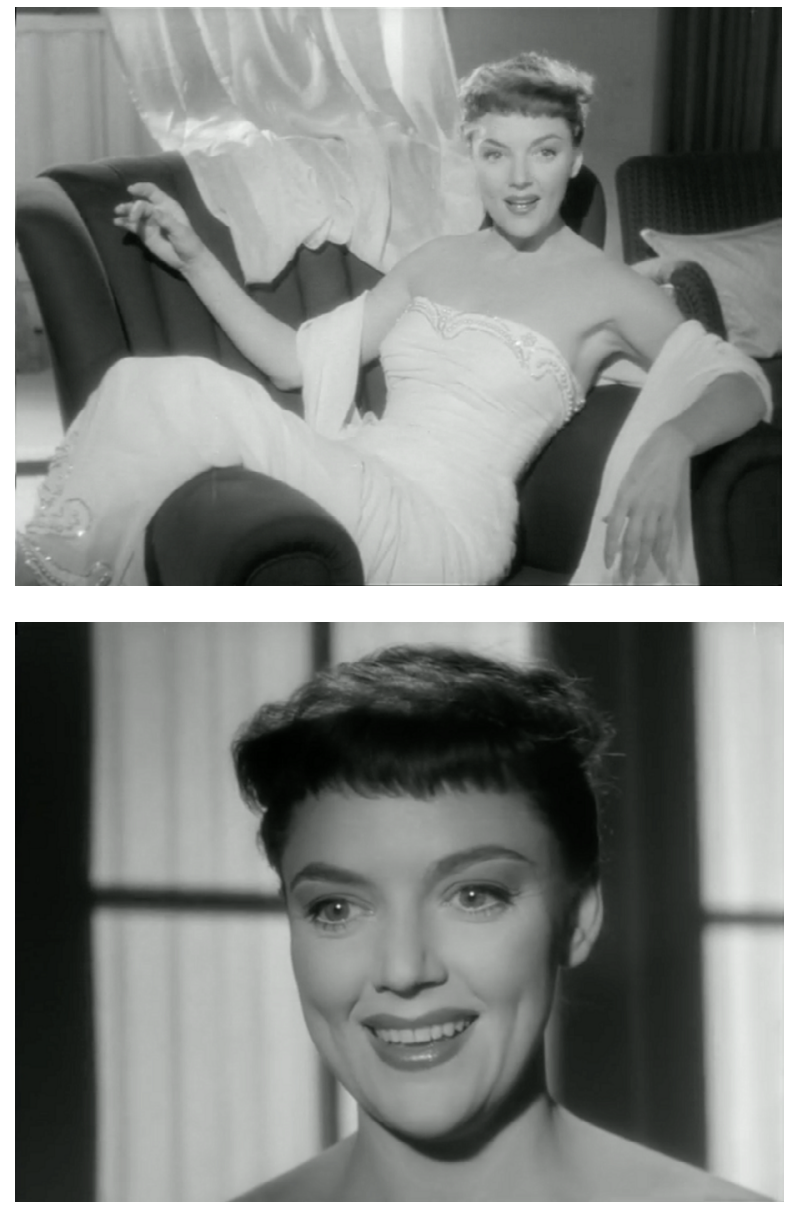

\section{Two Different Muses: One Razzie, One Crazy}

Terpsichore was to come down to earth in Hollywood again, but the result is disappointing to all who remember Rita's theophany. The Muse in Robert Greenwald's romantic musical-comedy Xanadu (1980) is played by Olivia Newton-John, a cutie who is largely personality-free (FIGURE 15). It also does not help that the film is set in disco-era Los 
Angeles. A young man who paints advertisements for a living tears up one of his drawings, and a scrap hits a large outdoor mural with an image of the nine Muses. These magically come to life and even get to sing about it: "I'm alive... Suddenly I am here today." One Muse, moving not on boogie-woogie, boogie-woogie dancing shoes but on roller skates, approaches him, kisses him, and disappears. Of course he is smitten. Romance is inevitable when, inevitably, he finds her (FIGURE 16). She, too, is ready to inspire: 'I'm not as I appear to you. Have you ever heard the expression 'kissed by a Muse'? I am - I'm a Muse... I come from Mt. Helicon. I'm a daughter of Zeus. I have eight sisters." These, too, are multicultural: white and Latina (FIGURE 17). But there are no black Muses, as Disney's five would later be.

FIGURE 15 - Xanadu (1980), poster

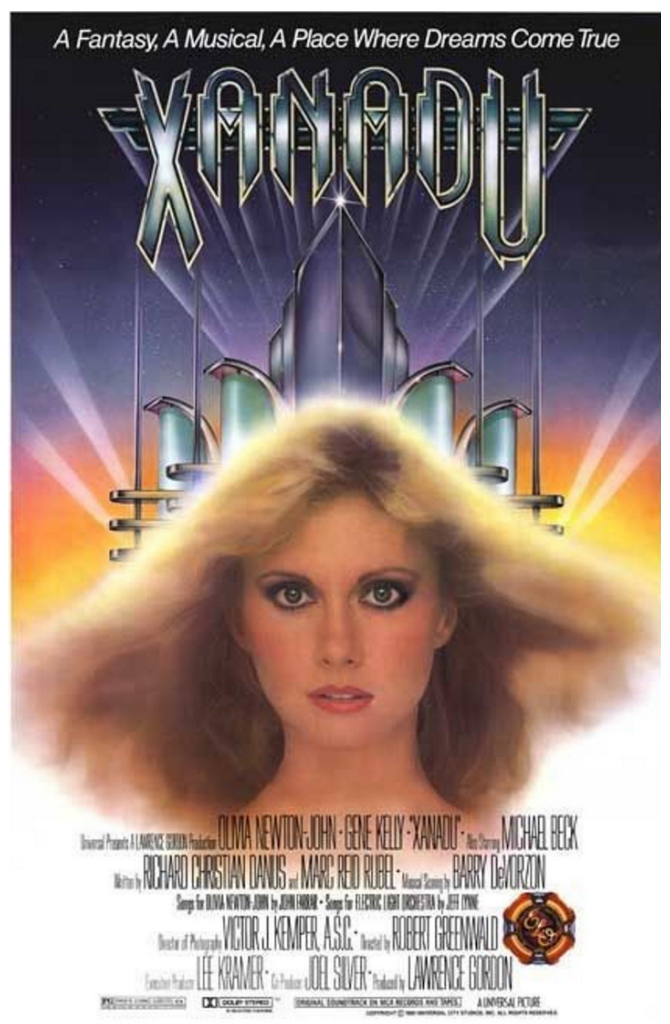


As was Polyhymnia, this Terpsichore is aware that a Muse should not love a mortal: "We're not supposed to feel emotion or show any feelings. Muses are just supposed to inspire. I fell in love... It was a mistake. I broke the rules." Still, she confesses: "I'll love you forever." The mural eventually turns out to be a kind of supernatural entrance to, or exit from, the Muses' realm. The young man enters and encounters the power of an unseen and not too bright Zeus, who grants Terpsichore to stay with her man, but only as a mortal.

FIGURE 16 - Xanadu (1980), lobby card

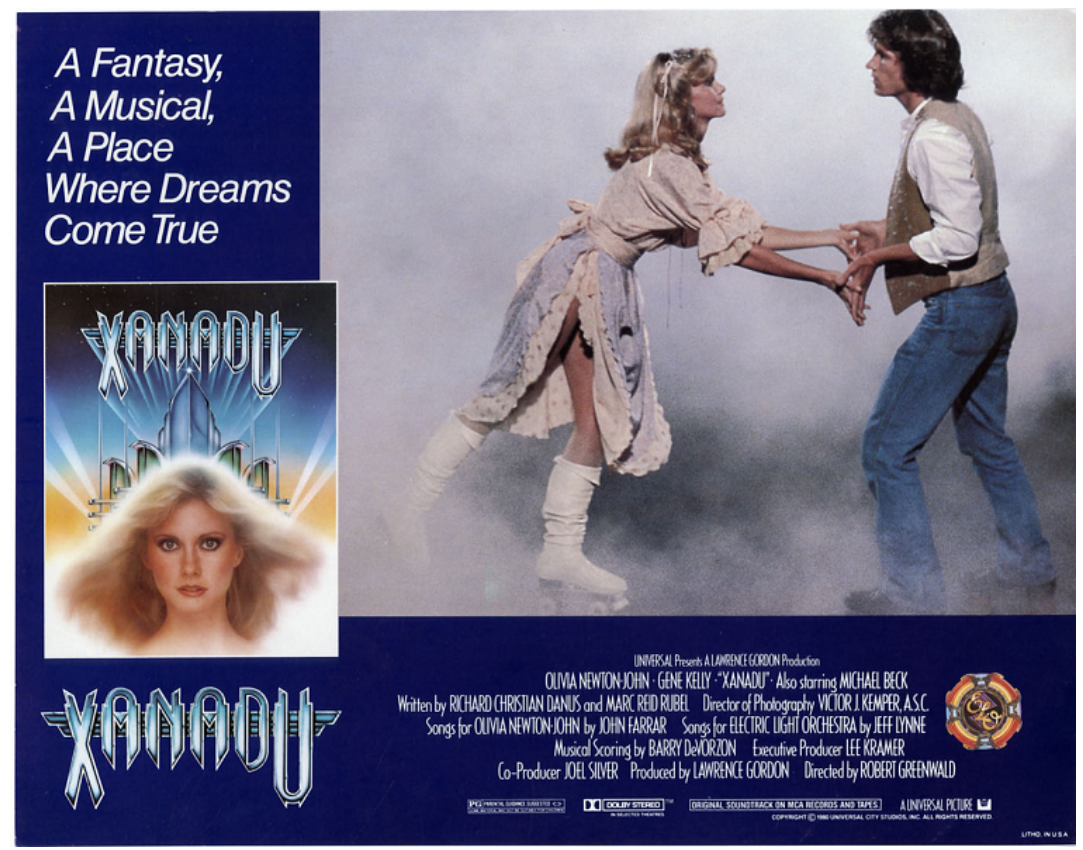

Xanadu, the eponymous disco, is not the stately pleasure dome that literate viewers might have expected, and Xanad $u$ did not make film history except in one regard. It inspired the Razzie Awards, a kind of antiOscar for Worst Achievement. Greenwald won the first Worst Director award. Apparently he and his screenwriters had not been kissed by any Muse. In Xanadu the Muses have come way, way down. 
FIGURE 17 - Xanadu (1980), lobby card

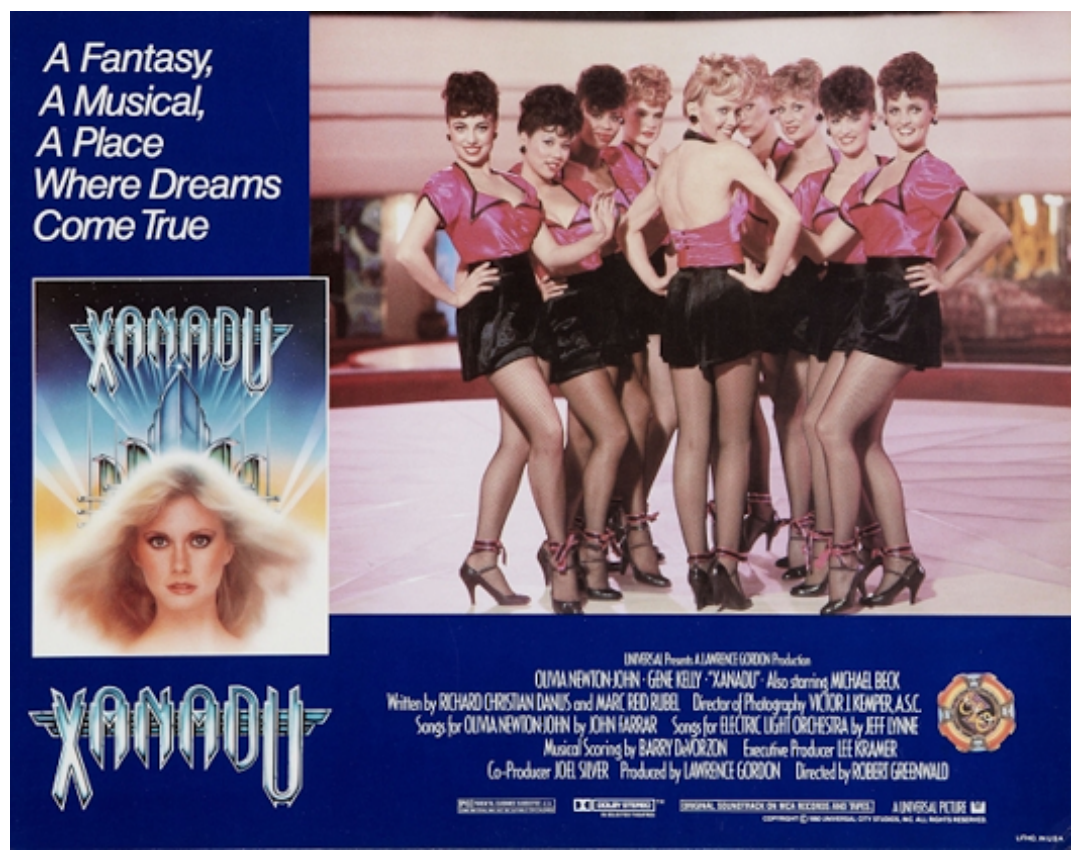

Faithful friends of the divine nine who watch Albert Brooks's comedy The Muse (1999) for the first time may be chagrined at its doubletwist ending (FIGURE 18). Brooks, who also co-wrote the script, plays a successful Hollywood screenwriter who suddenly finds out that his career is over because the screenplay on which he is currently working is considered weak. But help is at hand. A fellow screenwriter introduces him to a Muse called Sarah Little - she is not identified by any classical name-who is played by sex symbol Sharon Stone. One type of poster is reminiscent, probably intentionally, of seductive Mrs. Robinson in Mike Nichols's The Graduate of 1967 (FIGURE 19). Now things begin to look up for the writer, and the Muse even moves in with him and his wife. But Sarah expects expensive presents. The helpful friend explains that, if disappointed, she may turn her basic instinct for inspiration into the opposite: "You don't want to piss off a Muse... If you get them angry, they could do the opposite of what they're supposed to do... You 
might never think of another idea again." The writer's wife has figured this out, too: "The happier she is, the better Muse she is. Don't you want the best Muse you can get?" Appropriately, the Italian release was marketed under the title La dea del successo ("The Goddess of Success"; FIGURE 20). Funny moments involve famous directors James Cameron and Martin Scorsese, both playing themselves, as Sarah's clients. She advises Cameron against a sequel to his monster hit Titanic of 1997: "I just don't see you going back to the water any time soon."

FIGURE 18 - The Muse (1999), poster

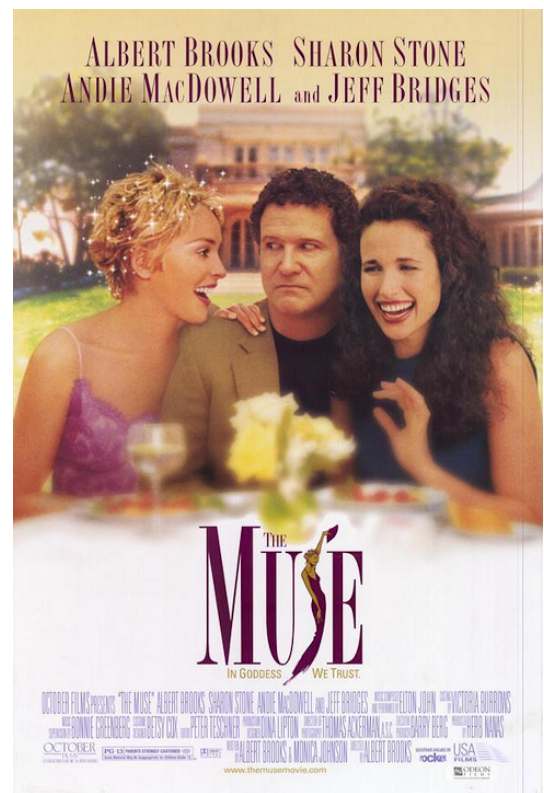

FIGURE 19 - The Muse (1999), lobby card

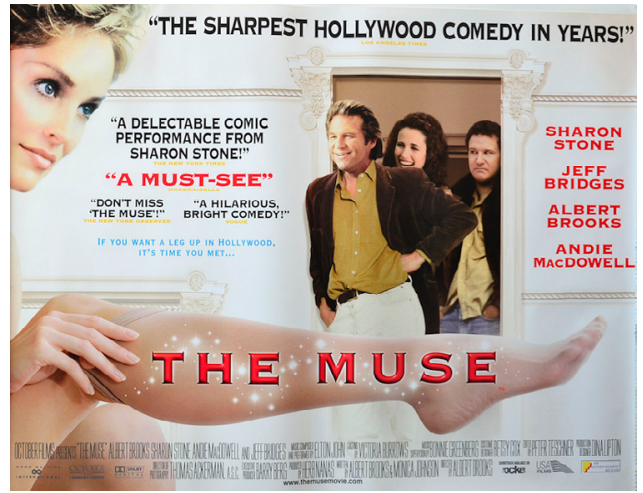

"In Goddess We Trust" proclaimed posters for the film. But the goddess turns out to be a phony: an escaped mental patient with multiplepersonality disorder. That is the first twist. Then the writer's script is accepted for production after all. The second twist, on which the film ends, reveals Sarah, under another name, as his new studio boss. She is still a material girl. 
FIGURE 20 - The Muse (1999), Italian poster

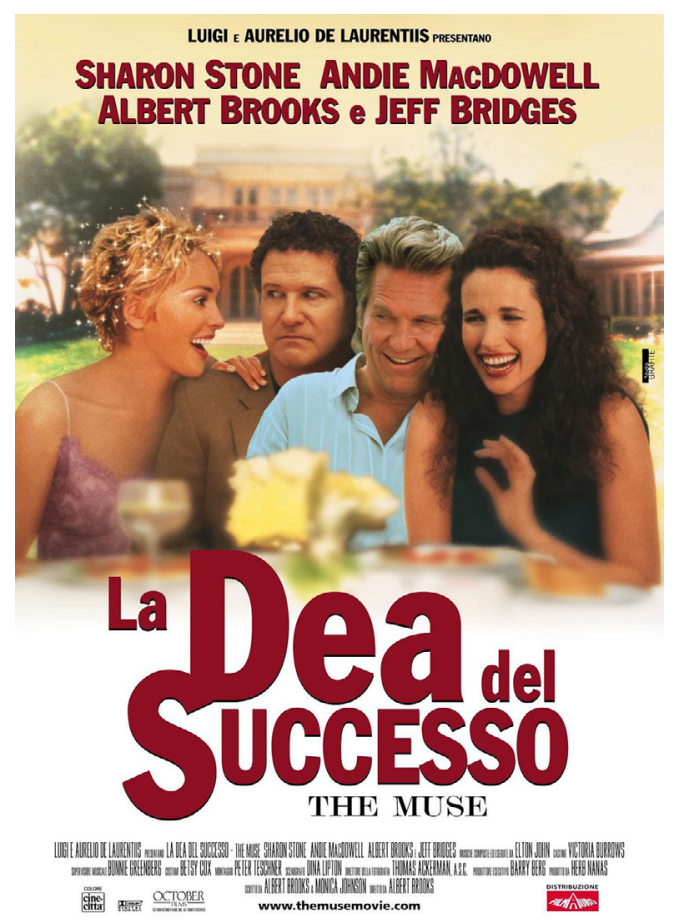

\section{A Muse for and from the Imagination}

With The Inner Life of Martin Frost (2007), American novelist, screenwriter, and director Paul Auster exemplifies how, in today's multimedia era, literature and images mutually reinforce each other.

Novelist Martin Frost has finished a project and takes a break in a secluded country house, where he begins writing a new story. Inexplicably he finds a beautiful young woman next to himself in his bed. She calls herself Claire Martin. They fall in love even before he realizes that she is his Muse. They enter into a passionate affair and decide to stay and live together. But on their drive to Martin's home in the city Claire mysteriously leaves him. He cannot bear her loss and returns to the solitary house, where he encounters Claire in dreams and visions (FIGURE 21). Martin then meets Anna, a second Muse, who 
is helping a hopeless amateur with his writings. Martin becomes her Svengali, and she stays with him. Claire, Anna, and presumably several other such Muses are sent to assist and inspire writers, and they assume an appearance that reflects their authors' intellectual levels. They also take on the first name of the individual they are to inspire as their own last name. Martin is an accomplished author, so Claire is very attractive. Anna, assigned to a mere scribbler, looks drab and is almost catatonic; only her association with Martin changes her into a pretty girl. These Muses leave their authors once their mission is accomplished and are then assigned to other writers. So they constantly assume and relinquish different bodies.

FIGURE 21 - The Inner Life of Martin Frost (2007), promotional photograph

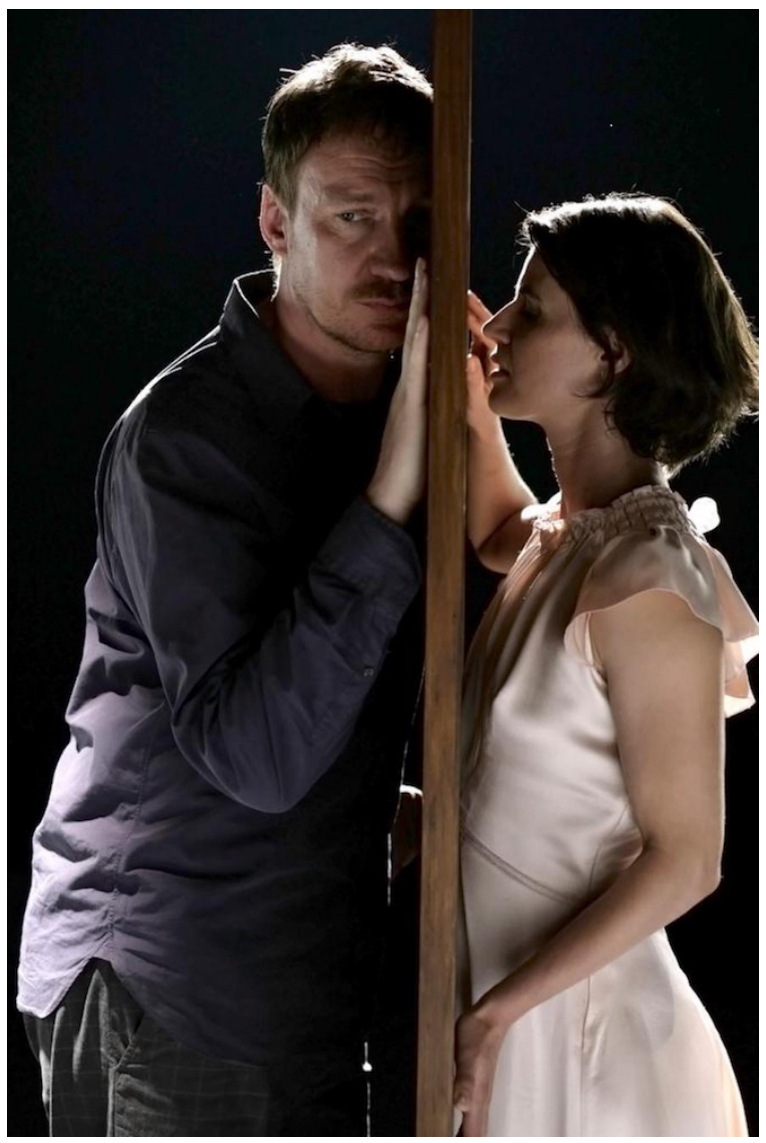


Auster had first written a screenplay for a short film, which he has summarized as follows:

The story of Martin Frost, a writer, and a mysterious woman who turns out to be his muse... But Claire isn't a traditional muse. She's an embodiment of the story Martin is writing, and the more he writes, the weaker she becomes - until, when he comes to the last word of the text, she dies. He finally figures out what has been happening and burns the manuscript in order to bring her back to life.

Auster eventually expanded his script into a feature film: "Martin brings Claire back to life - and then what? That's where the story would start to get even more interesting, I felt."

Anna makes Claire's return to Martin possible. Claire, we learn, had been forced to leave him against her will. Now she defies the powers of the otherworldly realm to which she and Anna belong. She informs Martin that certain conditions apply: "For the time being, I'm trapped between here and there." Then Claire finds a clever way to outwit the invisible powers and to go with Martin. Or does she?

The film's ending is highly complex. The sound of typewriter keys being struck fades in, and a cut reveals a typewriter in medium close-up. The camera zooms into a tight shot, and the volume on the soundtrack increases accordingly. But the typewriter we see is not being used; its keys are not moving, and there are no hands. The typewriter appears on a black screen as if it were floating in space. The effect is surreal. Another cut shows us an extreme and realistic close-up, from a different angle, on Martin as he is typing. Auster then dissolves to another close-up on Martin, his face turned almost directly to the camera as if he were looking out of the film's story. A second dissolve takes us to an extreme long shot of Martin's car moving along a country road. Wisps of fog at the top of the frame imbue the image with a supernatural aura. The car leaves the frame. After a cut to an empty black screen, the end credits roll.

\footnotetext{
${ }^{8}$ The quotations are from "The Making of The Inner Life of Martin Frost" (2006, interview with Céline Curiol), in Auster (2007, p. 1-19), on p. 1 and 2.
} 
All along, viewers have willingly suspended their disbelief in this modern, and at first realistic-looking, supernatural tale and have accepted the existence of Muses who appear from a different world. Everything cohered beautifully. But now we no longer know. Only on second viewing will we realize that the love story between Martin and Claire did not happen. There were no Muses. The only reality is of a solitary Martin writing his story involving Muses and then returning home. The film's title contains the decisive clue: the plot is about a writer's inner life, his creativity. Romantically inclined viewers may wish that it were not so, not least since elegant, charming, and beautiful Irène Jacob plays Claire. This Muse did not come down to earth but from the imagination. But then, all Muses do. Even Hesiod is unlikely to have encountered actual Muses and unlikely to have wanted his listeners and readers to believe that he had.

\section{The End; or: In the Beginning}

There are other films with other Muses, not all of them as classical or intriguing as most of those we have met here. They may be redheads like Rita, brunettes like Bodil, or blondes like Olivia and Sharon, but they will probably never be what Pindar called them: "violet-locked Muses." "Even so, the cinema provides us with a wide, if not an infinite, variety of Muses. Many famous actresses never embody Terpsichore, Polyhymnia, or any of the others. Their beauty is inspiring nonetheless, even without kisses. So I feel obliged to include a wholly subjective list of my own favorites-in fact, two lists. As already mentioned, besides the Greek Muses there were the Roman Camenae. Horace once referred to both together as "Greek Camenae." ${ }^{10}$ For this reason my lists are in Greek and Latin, with the names of actresses translated accordingly, sometimes literally, sometimes imaginatively (FIGURES 22-23). ${ }^{11}$ This is my token of gratitude to these ladies for the pleasure of their company over many years.

\footnotetext{
${ }^{9}$ Pindar, Isthmian Odes 7.23: ioplokoi Moisai.

${ }^{10}$ Horace, Odes 2.16.38: Graiae...Camenae.

${ }^{11}$ Both figures are reproduced from Winkler (2017, p. xiii-xiv). The book is dedicated to the actresses referred to in these lists, just as my earlier book (WINKLER, 2009) was dedicated to their leader Apollo.
} 
FIGURE 22 - The new Greek Muses

TAIE TOY MAPTINOY MơLAIL KINHMATOIPAФIKAIL TAIE NYN OA YMIIIAIE AI EILIN

Maptapithe XoptaziA - NeA TepwiXoph

BOAIA KIHP - NEA ПOAYMNIA

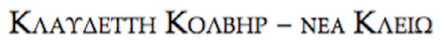

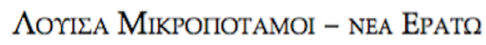

ФPanzOazH $\triangle$ OPAHAKH - NEA OTPanIA

XAPIL KEMAIA - NEA EYTEPIH

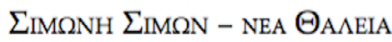

KaПYEINH - NEA KaAAIOIH

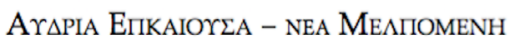

IEPA HAE H BIB $\Lambda O \Sigma$

FIGURE 23 - The new Roman Camenae

Camenis Martini cinematographicis

NOSTRI AEVI

QVAE SVNT

Daniela Darioea

Margarita Garbo

Liliana Gis

IOANNA HaRLo

VERONICA LACVS

Carola Longobarda

Loretta Novella

Silvia Sidnia

Norma Tonstrix

SACER HIC LIBER 
I would, however, be remiss if I omitted a Muse who takes us back to (almost) the beginnings of cinema. All cinephiles owe gratitude to Musidora, the earliest celluloid Muse. Her name means "Muses' Gift." It was the nom d'écran, as we may call it, of French actress Jeanne Roque (FIGURES 24-25). Roque seems to have been kissed by the Tenth Muse, for she later became a screenwriter, producer, and director. Posthumously she was the subject of a book and an hour-long documentary film, both called Musidora: la dixième muse (CAZALS, 1978, 2013).

FIGURES 24-25 - Promotional photographs of Jeanne Roque
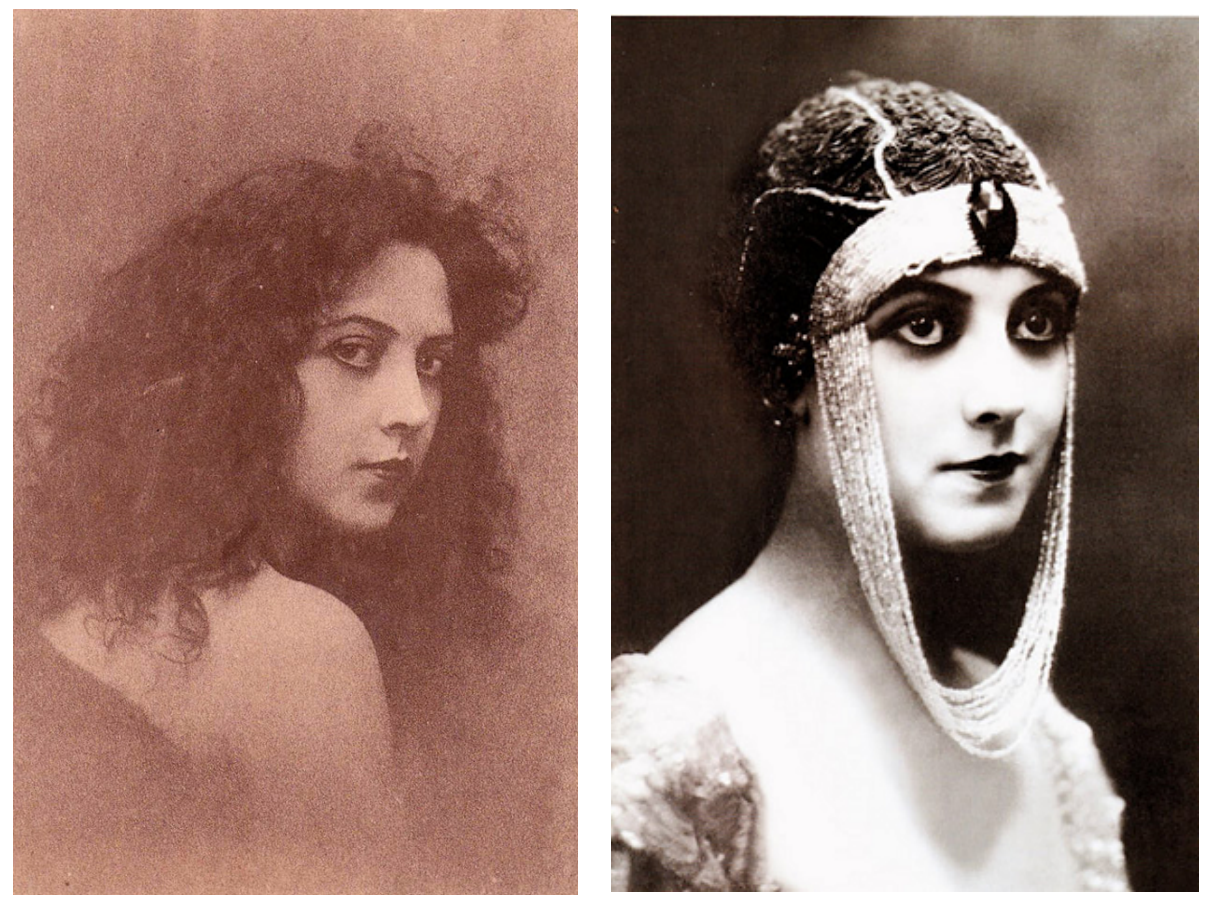
Musidora turned into an eternal star in 1915, when she played Irma Vep in Louis Feuillade's serial Les vampires (FIGURES 26-27). This is a thriller, so the titular vampires are not nocturnal bloodsuckers but a criminal gang masterminded by Mlle. Vep, famously dressed in a tight black catsuit, to which vampire-like "wings" could be added (FIGURES 28-29).

FIGURES 26-27 - Les Vampires (1915), posters
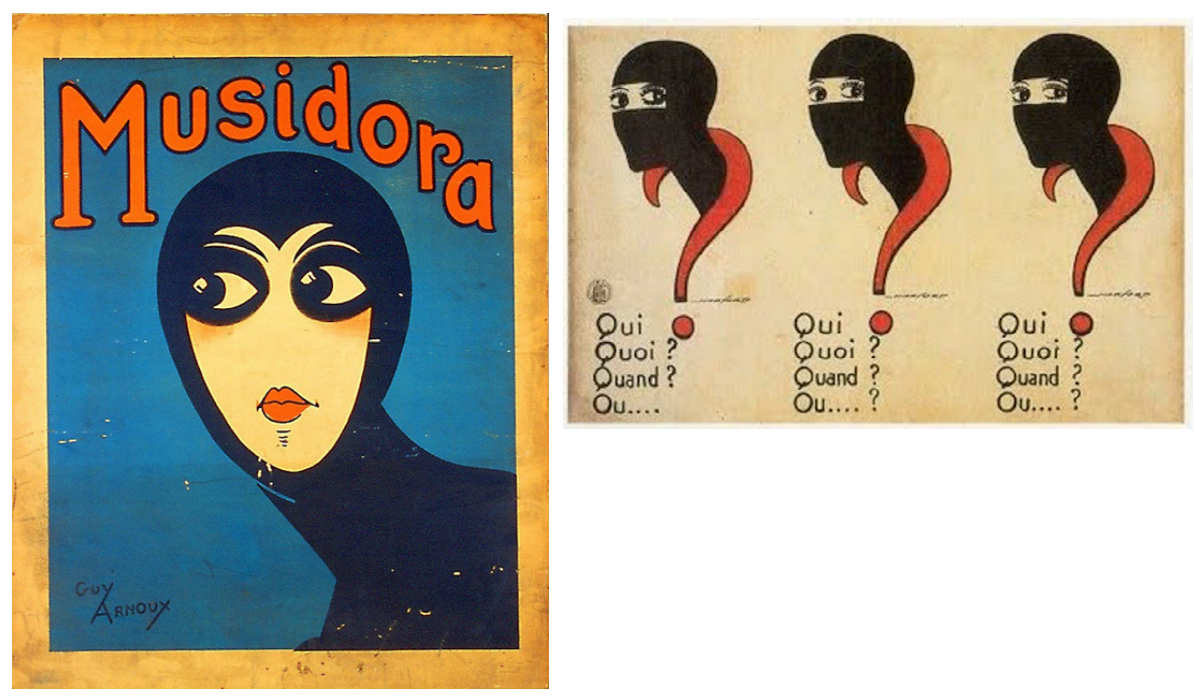
FIGURES 28-29 - Les Vampires (1915), screenshots
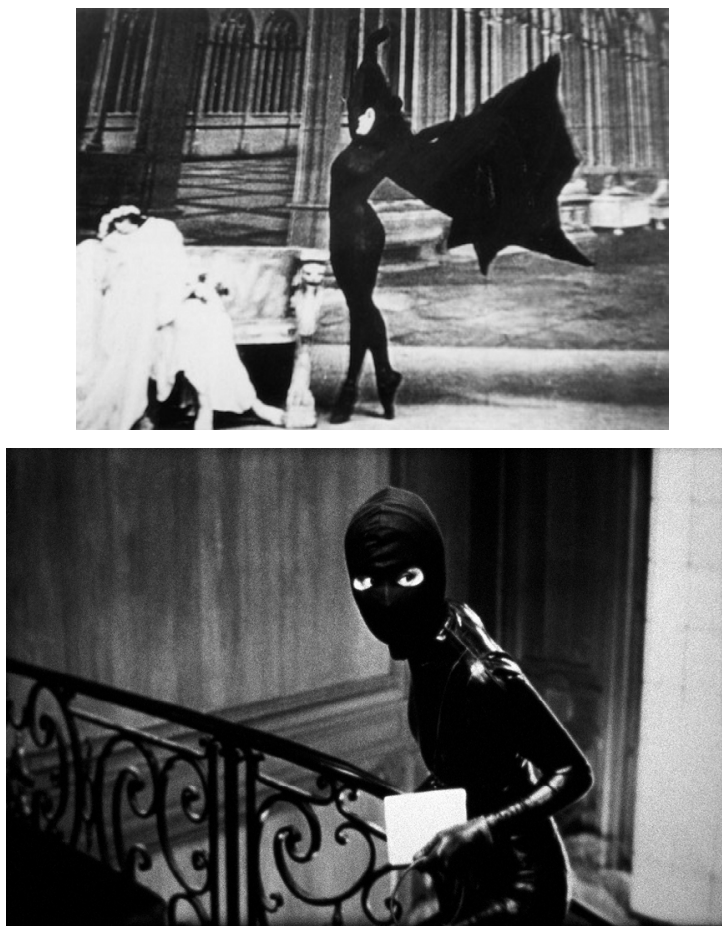

Olivier Assayas's Irma Vep (1996) with Hong Kong superstar Maggie Cheung in the title part is an affectionate tribute to our friend Irma, to Feuillade's film, and to silent cinema in general (FIGURE 30). Irma Vep is an anagram of vampire. This word in turn gave rise to the concept of the vamp, one of the most attractive, if often dangerous and destructive, manifestations of the fair sex on screen. 


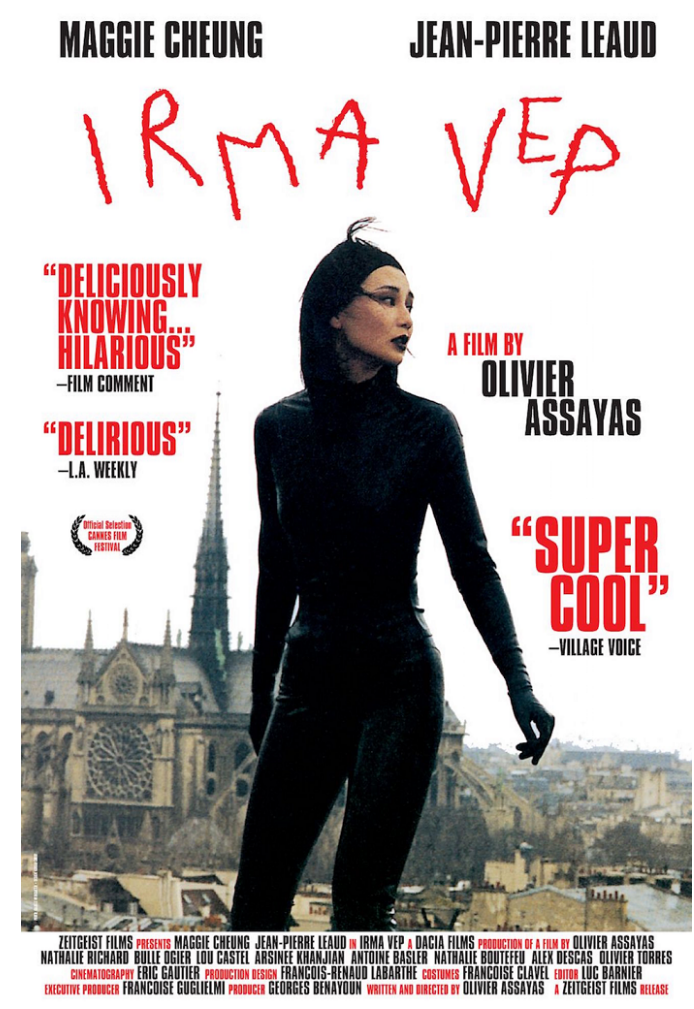

A case in point may be Muse (2015), a ten-minute film with Kat Graham, star of the American television series The Vampire Diaries (2009-2017). The short was directed by Darren Genet, who photographed many of the series' episodes and directed a few. The poster for Muse, a homage to French cinema in stylish black and white, is suitably film noir-ish (FIGURE 31). And is there not a reverse kind of inspiration since we read there: "She became his masterpiece"? Classical overtones here are minimal, but no matter: How impoverished the cinema would be without its vamping ladies! 


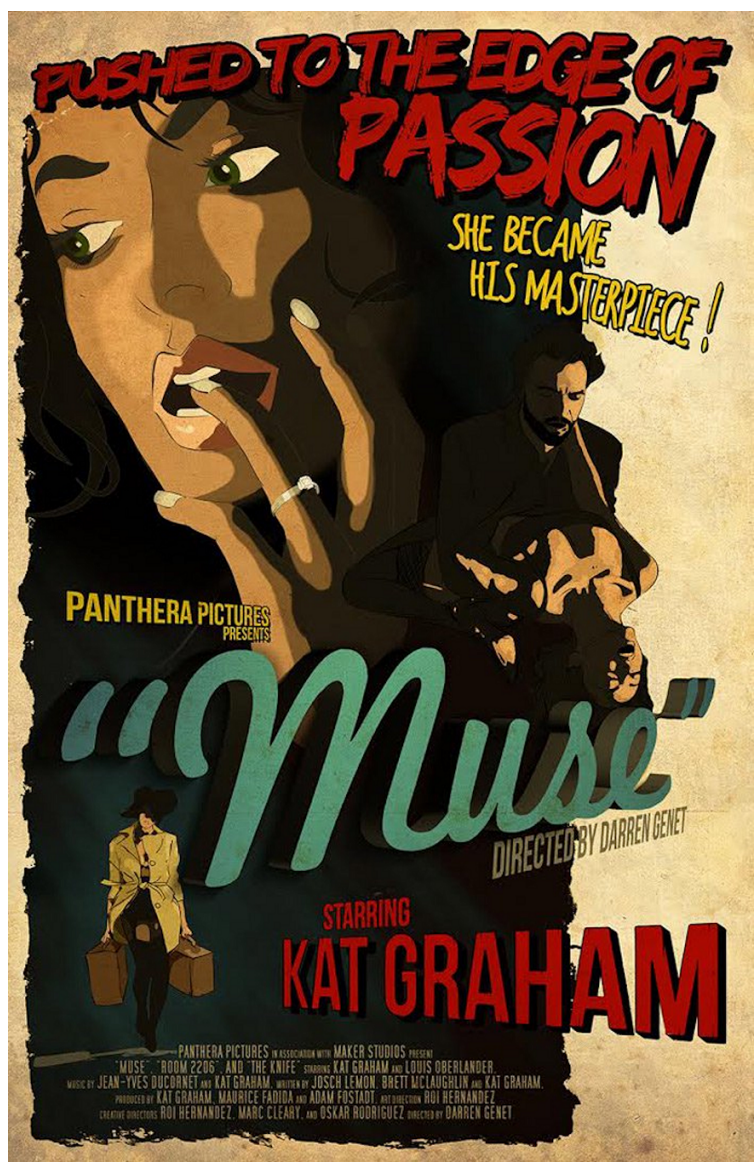

This particular gift provided by Musidora is indeed immortal. And irresistible. So, to close this brief tribute, I can do no better than to adapt the words of the Homeric Hymn quoted above to our Tenth Muse: 
With you, Muse, I begin... since from you...

the makers of films here on earth and their tales descend. Greetings, you new child of Zeus!

Or, more briefly and again in unmetrical Homeric terms: Kinêma moi ennepe, Mousa polytropê! And with this, dear reader, we bid our farewell to Rita and her sisters (FIGURE 32).

FIGURE 32 - Down to Earth (1947), screenshot

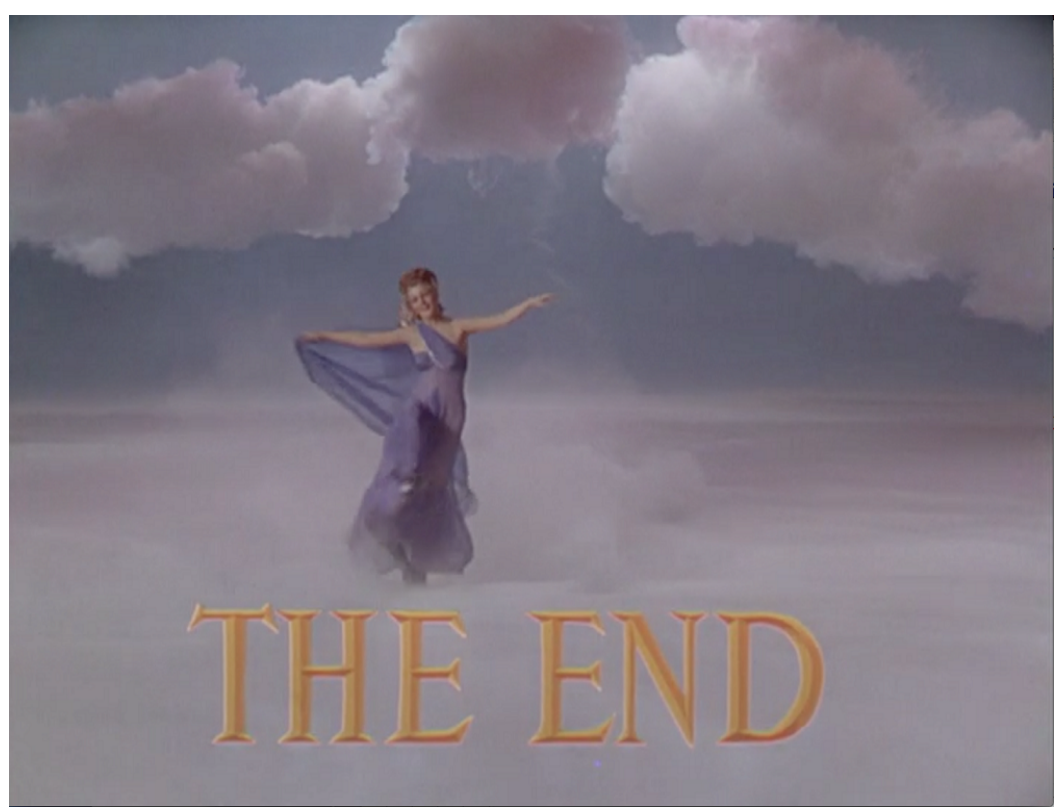




\section{References}

AUSTER, P. The Inner Life of Martin Frost. New York: Picador / Holt, 2007.

CAZALS, P. Musidora: la dixième muse. Paris: Centre National de la Cinématographie, 2013 (65 minutes).

CAZALS, P. Musidora: la dixième muse. Paris: Veyrier, 1978.

COCTEAU, J. The Art of Cinema. Edited by A. Bernard and C. Gauteur. Translated by R. Buss. London: Boyars, 1992.

FRAIGNEAU, A. Cocteau on the Film: Conversations with Jean Cocteau. Translated by Vera Traill. New ed. New York: Dover, 1972.

GAGETTI, E. Omero e la decima Musa: le mura di Troia. In: COLPO, I.; FAVARETTO, I.; GHEDINE, F. (ed.). Iconografia 2006: gli eroi di Omero. Rome: Edizioni Quasar, 2007. p. 269-279.

LIFE'S Cover. LIFE, New York, p. 29, 10 Nov. 1947.

MARCUS, L. The Tenth Muse: Writing about Cinema in the Modernist Period. Oxford: Oxford University Press, 2007.

PUCCI, G. Orfeo e la decima Musa. In: GUIDORIZZI, G.; MELOTTI, M. (eds.). Orfeo e le sue metamorfosi. Rome: Carocci, 2005. p. 168-178.

SARGEANT, W. The Cult of the Love Goddess in America. LIFE, New York, Nov. 10, 1947. p. 81-82, 85-86, 89-90, 92, 94, 96.

WINKLER, M. M. Cinema and Classical Texts: Apollo's New Light. Cambridge: Cambridge University Press, 2009.

WINKLER, M. M. Classical Literature on Screen: Affinities of Imagination. Cambridge: Cambridge University Press, 2017.

Recebido em: 16 de setembro de 2018. Aprovado em: 17 de novembro de 2018. 